\title{
Hepatocyte Transplantation
}

\author{
Ragai R Mitry, Robin D Hughes, Anil Dhawan \\ Institute of Liver Studies, King's College London School of Medicine at King's College Hospital, London, UK
}

\begin{abstract}
Hepatocyte transplantation (HTx) has been developed for use in liver-based metabolic disorders and in acute liver failure. Worldwide, there are around 80 patients that have been transplanted with hepatocytes. Almost all reported studies prove feasibility and safety of the procedure with short- to medium-term success. Availability of good quality hepatocytes (HCs) is the main limiting factor, and therefore alternative sources of cells such as stem cells are being investigated. Other limiting factors include cell engraftment, survival, and function of transplanted cells. It remains to be seen if progress in HTx research can overcome these hurdles leading to the wider use of the technique as an alternative to liver transplantation in the future. (J CLIN ExP HEPATOL 2011;1:109-114)
\end{abstract}

$\mathrm{L}$ iver transplantation (LTx) is the only wellestablished treatment for both acute and chronic end-stage liver diseases and liver-based metabolic conditions such as ornithine transcarbamylase (OTC) deficiency. However, shortage of donor organs available for transplantation remains a major problem, with deaths occurring while awaiting LTx. Hence, alternative treatments such as hepatocyte transplantation (HTx) may delay whole organ replacement or obviate the need altogether for orthotopic LTx.

Hepatocyte transplantation is being developed as an alternative treatment for the management of acute liver failure (ALF) and liver-based metabolic disorders. ${ }^{1-8}$ Compared with LTx, HTx has several advantages: (a) being less invasive, with less morbidity and mortality, (b) the native liver remains in situ allowing the possibility of regeneration over time and recovery in the setting of ALF, or at least buying the patient time until a suitable organ is available for transplantation.

\section{Pre-clinical Studies}

Mito and colleagues (1979) demonstrated that ectopically transplanted rat hepatocytes (HCs) survived outside the liver. ${ }^{9}$ Pre-clinical HTx studies in vivo had started in the late 1970s, and showed that the technique was feasible

Keywords: Acute liver failure, hepatocyte transplantation, liver disease, stem cell transplantation

Received: 18.07.2011; Accepted: 19.07.2011

Address for correspondence: Anil Dhawan, Professor, Paediatric Liver Service, King's College Hospital, Denmark Hill, London SE5 9RS, UK

E-mail: anil.dhawan@kcl.ac.uk

Abbreviations: ALF: acute liver failure; ApoB: apolipoprotein B; EGTA: ethylene glycol-bis(2-aminoethylether)-N,N,N',N'-tetra-acetic acid; FVII: factor VII deficiency; GMP: good manufacturing practice; HAS: human serum albumin; HC: hepatocytes; HTx: hepatocyte transplantation; LDL: low density lipoprotein; LTx: liver transplantation; MRI: magnetic resonance imaging; OTC: ornithine transcarbamylase doi: 10.1016/S0973-6883(11)60129-1 and safe, with some studies reporting success in animals (reviewed in Weber et al 2009). ${ }^{10}$ There are published animal model studies of HTx which includes the Gunn rat for Crigler-Najjar syndrome type I, Nagase analbuminemic rats for hypoalbuminemia, Spf-ash mice for OTC deficiency, dogs for hyperuricosemia, and others. These studies showed that it is possible to achieve medium to long-term improvements in their biochemical abnormalities. In the case of ALF, there are rodent models including D-galactosamine, 90\% hepatectomy, and liver ischemic injury (Table 1). These studies also showed improvements in the condition and survival of the animals; however, there are questions that remain unanswered as results in animal models are not always transferable to man.

\section{Clinical Studies}

There are a number of centers worldwide that have reported their experience of clinical HTx. None of these studies demonstrated a complete cure; however, many of them reported improvement in phenotype from severe to moderate

Table 1 Examples of animal models corresponding to human liver conditions.

\begin{tabular}{llc}
\hline Human liver problem & Animal model & References \\
\hline Crigler-Najjar type 1 & Gunn rat & 11 \\
\hline $\begin{array}{l}\text { Familial hyper- } \\
\text { cholesterolemia type 1 }\end{array}$ & Watanabe rabbit & 12 \\
$\begin{array}{l}\text { Hereditary tyrosinemia } \\
\text { type 1 }\end{array}$ & Fah $^{-} /^{-}$mouse & 13 \\
$\begin{array}{l}\text { Progressive familial } \\
\text { intrahepatic cholestasis }\end{array}$ & Mdr2- $/^{-}$mouse & 14 \\
$\begin{array}{l}\text { Wilson's disease } \\
\text { X-linked severe combined } \\
\text { immunodeficiency }\end{array}$ & $\begin{array}{l}\left.\text { Rag2- }{ }^{-} \text {gamma(c) }\right)^{-} /^{-} \\
\text {mouse }\end{array}$ & 16 \\
\hline
\end{tabular}

Fah: fumarylacetoacetate hydrolase; Mdr2: multidrug resistance protein 2; Rag2: recombination activation gene 2 . 
or mild. The indications included (a) liver-based metabolic disorders such as OTC deficiency, arginine succinyl lyase deficiency, citrullinemia, Crigler-Najjar syndrome type I, glycogen storage disease $1 \mathrm{a}$ and $1 \mathrm{~b}$, Refsum's disease, factor VII deficiency (FVII), progressive familial intrahepatic cholestasis type II, and hypercholesterolemia; (b) ALF, and a few reports on chronic liver disease (Tables 2 and 3 ).

\section{Hepatocytes Isolation}

Hepatocytes are isolated from donor liver tissues unused/ rejected for transplantation (mainly due to being steatotic) using a collagenase perfusion technique (Figures 1 and 2). ${ }^{41}$ The procedure must be carried out under strict sterile conditions, i.e. under Good Manufacturing Practice (GMP) standards in a clean room. Major vessels of liver tissue are cannulated, and the cannulae are secured in a place using suitable sutures. The tissue is then perfused with warm $\left(37^{\circ} \mathrm{C}\right)$ buffer solutions. The first solution contains Ethylene glycol-bis(2-aminoethylether)-N,N, $\mathrm{N}^{\prime}, \mathrm{N}^{\prime}$-tetra-acetic acid (EGTA) to chelate calcium ions to break up desmosomes between the HCs, which makes it easier for collagenase to digest the tissue. The second solution is a plain buffer to wash out the EGTA as collagenase requires calcium ions in order to function optimally. The third solution contains collagenase which digests the tissue. Once the tissue digestion is complete, the HCs are released in a crude cell suspension. The HCs are then purified by repeated wash steps and slow speed centrifugation. The wash buffer solution is used ice cold and supplemented with human serum albumin (HAS) which will inhibit collagenase action and prevent tissue over-digestion, i.e. prevent killing of the released HCs. The cell number and viability are then estimated using a standard trypan blue test. It must be noted that the quality of the isolated HCs will depend on the quality of the liver tissue from which they were isolated.

It is best to transplant HCs fresh, but if no patient is waiting, these HCs can be cryopreserved using optimized protocols, ${ }^{24}$ though there will be some loss of HC metabolic function on thawing.

Table 2 Summary of hepatocyte transplantation clinical studies in liver-based metabolic diseases.

\begin{tabular}{|c|c|c|c|}
\hline Liver disease & No. of patients & Overall outcome & References \\
\hline $\begin{array}{l}\text { Ornithne transcarbamylase } \\
\text { deficiency }\end{array}$ & 5 & $\begin{array}{l}\text { Ranged from some stabilization to decrease in ammonia and } \\
\text { detection of urea synthesis }\end{array}$ & $4,6,8,17,18$ \\
\hline Arginine succinyl lyase deficiency & 1 & $\begin{array}{l}\text { Decrease in ammonia, and detection of transplanted cells } \\
\text { using fluorescent in situ hybridization }\end{array}$ & 19 \\
\hline Citrullinemia & 1 & Decrease in ammonia & 20 \\
\hline Crigler-Najjar type I & 8 & $30-50 \%$ decrease in bilirubin up to 7 months & $21-27$ \\
\hline Glycogen storage disease $1 \mathrm{a}$ & 1 & Better fasting, and decrease in triglyceride for up to 18 months & 28 \\
\hline Glycogen storage disease $1 b$ & 1 & $\begin{array}{l}\text { Improvements in glucose levels, with detectable normal } \\
\text { enzyme level on biopsy }\end{array}$ & 29 \\
\hline Refsum disease & 1 & $\begin{array}{l}\text { Partial clearance of bile salts, with improvement in } \\
\text { development to } 18 \text { months }\end{array}$ & 30 \\
\hline Factor VII deficiency & 3 & Drop in recombinant FVII requirement to $20 \%$ of pre OLT levels & 7 \\
\hline $\begin{array}{l}\text { Progressive familial intrahepatic } \\
\text { cholestasis type II }\end{array}$ & 2 & No benefit; OLT at 5 and 14 months post cell transplantation & $\begin{array}{l}\text { Unpublished } \\
\text { data }\end{array}$ \\
\hline Hypercholesterolemia & 5 & $\begin{array}{l}\text { Ranged from no effect to } 20 \% \text { decrease in cholesterol level, } \\
\text { low density lipoprotein (LDL), and apolipoprotein B (ApoB) }\end{array}$ & 31 \\
\hline
\end{tabular}

OLT: orthotopic liver transplant.

Table 3 Summary of hepatocyte transplantation clinical studies in acute and acute on chronic liver failure.

\begin{tabular}{|c|c|c|c|}
\hline Liver disease & No. of patients & Overall outcome & References \\
\hline \multicolumn{4}{|l|}{ Acute liver failure } \\
\hline Drug & 17 & Ranged from no effect to full recovery without OLT & $1-3,20,22$ \\
\hline Viral & 10 & Ranged from no effect to full recovery without OLT & $1-3,18,20,33,34$ \\
\hline Miscellaneous & 14 & Ranged from no effect to full recovery without OLT & $3,20,32,34-37$ \\
\hline \multicolumn{4}{|l|}{ Acute on chronic liver failure } \\
\hline Alpha 1 antitrypsin deficiency & 2 & OLT 2 and 4 days & 3,4 \\
\hline Viral & 1 & $\mathrm{ICH}$ bleed; died & 4 \\
\hline Alcohol & 5 & 3 alive, and 2 died & 1,3 \\
\hline Miscellaneous & 6 & Decreased bilirubin in 1; 2 died; 2 OLT & $3,38-40$ \\
\hline
\end{tabular}

OLT: orthotopic liver transplant; ICH: intracranial hemorrhage. 


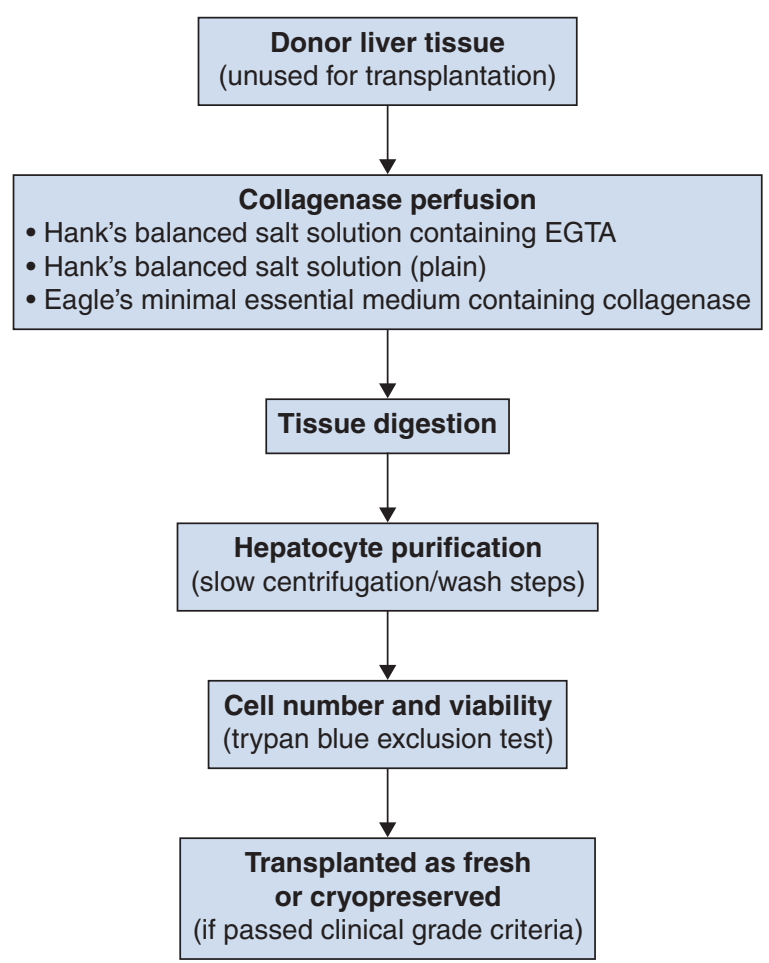

Figure 1 Main stages for hepatocytes isolation and handling. EGTA: Ethylene glycol-bis(2-aminoethylether)-N,N,N',N'-tetra-acetic acid.

\section{Preparation of Hepatocytes for Clinical Use}

Every HTx center has set criteria for releasing the HCs for clinical use. From our experience at the King's College Hospital, London, the criteria for releasing clinical grade HCs must be (a) blood group ABO compatible, (b) have cell viability of $\geq 60 \%$, (c) negative viral screening as for whole organ transplantation, and (d) micro-organism free on Gram stain immediately prior to administration. Up to $2.4 \times 10^{6}$ cells/g native liver may be transplanted, with a maximum total number of HCs of $5 \times 10^{8}$ per infusion. The goal is to transplant a total mass of cells equivalent to $10 \%$ of the recipient's liver mass or $1 \times 10^{8} \mathrm{HCs} / \mathrm{Kg}$ body weight. The cell preparation composition is HCs $\left(1 \times 10^{7} /\right.$ $\mathrm{mL}$ ) in a transplant medium (usually M199), HAS (3\%, v/v), and heparin $(1 \mathrm{U} / \mathrm{mL})$.

\section{Route of Administration of Hepatocytes}

Animal models for HTx suggested that there are several possible sites suitable for cell transplantation; however, in humans, the preferred route for metabolic indications is intraportal. Portal circulation can be accessed by the direct portal vein puncture, the operative insertion of a central venous catheter in portal venous tributaries, or the umbilical vein in neonates. The portal pressure should be measured after every infusion (infusion time 5-10 $\mathrm{min}$ ), and subsequent infusions to continue as long as the portal pressure stays below a persistent increase of $12 \mathrm{mmHg}$.

\section{Possible Complications}

There are a few complications that may be observed which include transient portal hypertension, sepsis, embolization to pulmonary capillary beds, and hemodynamic instability. There is also the possibility of portal plugging; however, the resulting ischemia could be minimized by limiting the number of cells per infusion, slow speed of infusion, and the addition of heparin to the cell preparation. Immunosuppression is also required, which is a similar regimen to that used in LTx.

\section{Fate of Transplanted Cells}

One of the challenges is monitoring and tracking cells following transplantation in man. The fate of these cells is dependent on their interaction with the local environment. Animal studies showed that it is possible to track transplanted HCs. However, these cells were labeled with, for example, green fluorescent protein. ${ }^{42,43}$ New techniques for labeling cells are emerging using superparamagnetc iron oxide particles (contrast agent) in vitro, followed by transplantation; then cells can be tracked/monitored in vivo using magnetic resonance imaging (MRI). Clinical grade MRI contrast agents can be used ${ }^{44}$; however, the MRI images obtained will show both the transplanted labeled cells and other cells in the recipient liver that have taken up the contrast agent after release from dying transplanted cells.

Transient sinusoidal "blockage" in the liver occurs immediately after cell transplantation. A large number of these HCs will die as a result of hypoxia and congestion, while the remainder will be attacked by the immune system. Therefore, immunosuppression is considered essential. The immunosuppression regimen includes corticosteroids and calcineurin inhibitors. ${ }^{45}$ Based on the islet transplantation protocol, a new approach is being evaluated where monoclonal antibodies like daclizumab (an IL-2 receptor monoclonal antibody) with low dose tacrolimus and sirolimus are also in vogue. ${ }^{46}$ Monitoring rejection is difficult. Currently, the missing enzyme activity product changes are used as crude markers such as elevation of bilirubin in Crigler-Najjar syndrome type I and detoxification of ammonia by conversion into urea.

\section{Other Cell Sources}

As mentioned above, the quality of donor liver tissues offered for $\mathrm{HC}$ isolation continues to be poor, and hence the need for alternative sources of good quality HCs from stem-cell-based techniques. Stem/progenitor cells have many advantages including ease of expandability in vitro and in vivo. They can be autologous cells, and therefore avoid the need to use immunosuppression, and also it is believed that they are less immunogenic. ${ }^{11,47}$ Table 4 summarizes the possible sources of stem/progenitor cells, and their advantages and disadvantages. 

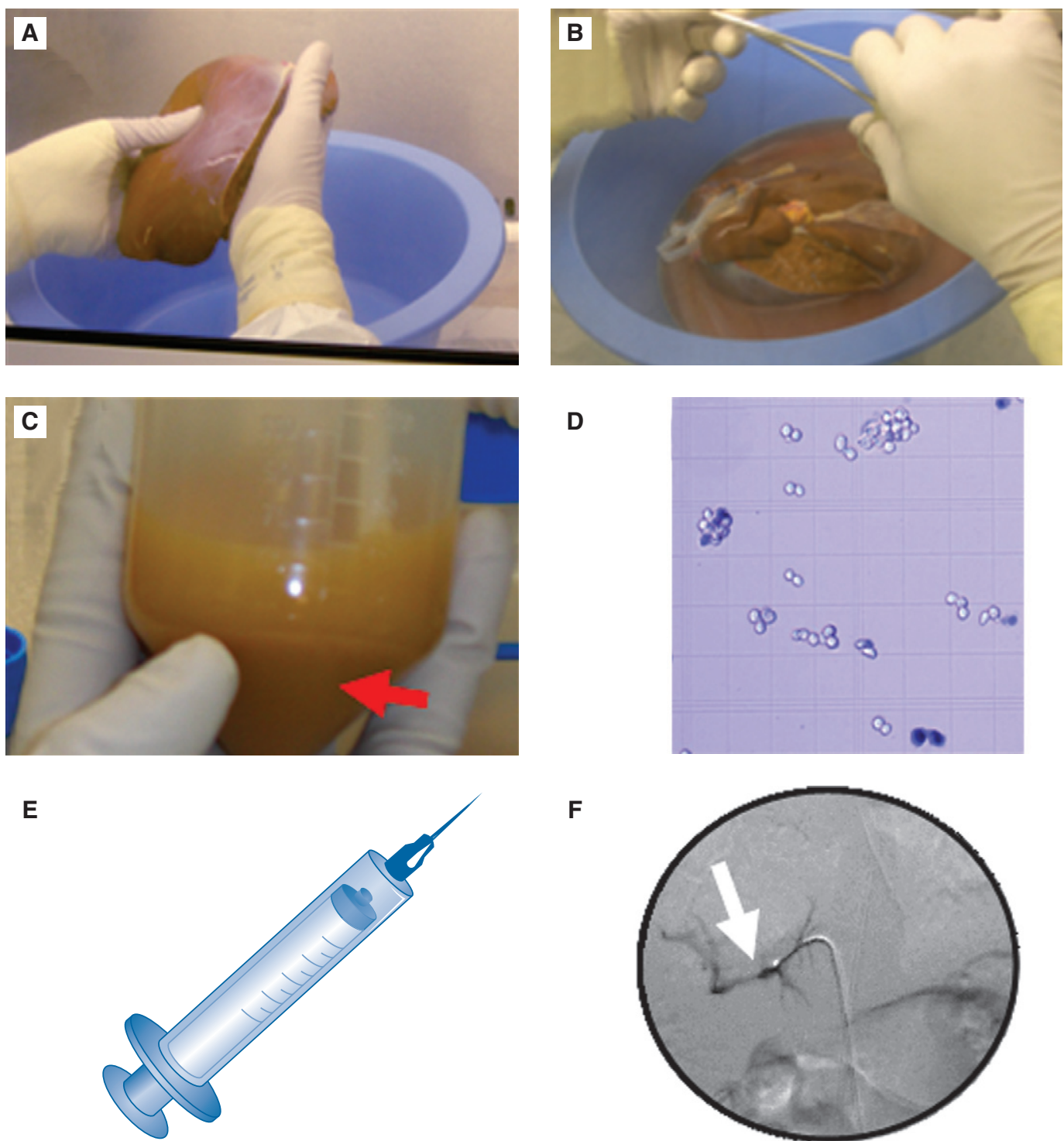

Figure 2 Isolation and preparation hepatocytes for transplantation. (A) Right lobe of the donor liver to be processed; (B) cannulation of major vessels on the cut surface of the tissue; $(C)$ following tissue collagenase digestion, hepatocytes are pelleted (indicated by a red arrow) by centrifugation; (D) cell viability is checked with trypan blue, dead cells will stain blue; $(E)$ cell suspension is ready to be infused; (F) an example of cells being infused in the right part of the liver using a long catheter through the umbilical vein (white arrow indicates end of catheter in liver).

Table 4 Stem cell sources of hepatocyte-like cells: advantages and disadvantages.

\begin{tabular}{lll}
\hline Stem cells & Advantages & Disadvantages \\
\hline Embryonic & - Availability & - Possibly tumorigenic \\
& - Expandability & - Hepatocyte-like functions (incomplete functions) \\
Fetal & - Less immunogenic & \\
& - Proliferative potential & - Difficult to obtain \\
Hematopoietic & - Availability & - Hepatocyte-like functions (incomplete functions) \\
- Function demonstrated in animals & - Possible fusion and nuclear damage \\
Mesenchymal & - Availability & - Possibly tumorigenic \\
& - Expandability & - Fomplete differentiation \\
- Less immunogenic potential & \\
\hline \multirow{2}{*}{ Liver-specific progenitor cells } & - Can be autologous & \\
& - Availability & - Possible fusion and nuclear damage \\
\hline
\end{tabular}




\section{CONCLUSION}

In summary, HTx is becoming established as an alternative technique for treatment of certain liver diseases. Improvements in the availability of suitable cells are needed before wider application of liver cell therapy.

\section{CONFLICTS OF INTEREST}

No conflict of interest was declared.

\section{REFERENCES}

1. Bilir BM, Guinette D, Karrer F, et al. Hepatocyte transplantation in acute liver failure. Liver Transpl 2000;6:32-40.

2. Strom SC, Fisher RA, Thompson MT, et al. Hepatocyte transplantation as a bridge to orthotopic liver transplantation in terminal liver failure. Transplantation 1997;63:559-69.

3. Strom SC, Chowdhury JR, Fox IJ. Hepatocyte transplantation for the treatment of human disease. Semin Liver Dis 1999;19:39-48.

4. Strom SC, Fisher RA, Rubinstein WS, et al. Transplantation of human hepatocytes. Transplant Proc 1997;29:2103-6.

5. Horslen SP, Fox IJ. Hepatocyte transplantation. Transplantation 2004;77:1481-6.

6. Horslen SP, McCowan TC, Goertzen TC, et al. Isolated hepatocyte transplantation in an infant with a severe urea cycle disorder. Pediatrics 2003;111:1262-7.

7. Dhawan A, Mitry RR, Hughes RD, et al. Hepatocyte transplantation for inherited factor VII deficiency. Transplantation 2004;78:1812-4.

8. Mitry RR, Dhawan A, Hughes RD, et al. One liver, three recipients: segment IV from split-liver procedures as a source of hepatocytes for cell transplantation. Transplantation 2004;77:1614-6.

9. Mito M, Ebata H, Kusano M, Onishi T, Hiratsuka M, Saito T. Studies on ectopic liver utilizing hepatocyte transplantation into the rat spleen. Transplant Proc 1979;11:585-91.

10. Weber A, Groyer-Picard MT, Franco D, Dagher I. Hepatocyte transplantation in animal models. Liver Transpl 2009;15:7-14.

11. Le Blanc K, Tammik C, Rosendahl K, Zetterberg E, Ringden O. HLA expression and immunologic properties of differentiated and undifferentiated mesenchymal stem cells. Exp Hematol 2003;31: 890-6.

12. Groth CG, Arborgh B, Bjorken C, Sundberg B, Lundgren G. Correction of hyperbilirubinemia in the glucuronyltransferasedeficient rat by intraportal hepatocyte transplantation. Transplant Proc 1977;9:313-6.

13. Eguchi S, Rozga J, Lebow LT, et al. Treatment of hypercholesterolemia in the Watanabe rabbit using allogeneic hepatocellular transplantation under a regeneration stimulus. Transplantation 1996;62:588-93.

14. Azuma H, Paulk N, Ranade A, et al. Robust expansion of human hepatocytes in Fah-/-/Rag2-/-/II2rg-/-mice. Nat Biotechnol 2007; 25:903-10.

15. De Vree JM, Ottenhoff R, Bosma PJ, Smith AJ, Aten J, Oude Elferink RP. Correction of liver disease by hepatocyte transplantation in a mouse model of progressive familial intrahepatic cholestasis. Gastroenterology 2000;119:1720-30.

16. Malhi H, Joseph B, Schilsky ML, Gupta S. Development of cell therapy strategies to overcome copper toxicity in the LEC rat model of Wilson disease. Regen Med 2008;3:165-73.

17. DiSanto JP, Muller W, Guy-Grand D, Fischer A, Rajewsky K. Lymphoid development in mice with a targeted deletion of the interleukin 2 receptor gamma chain. Proc Natl Acad Sci USA 1995; 92:377-81.

18. Stephenne X, Najimi M, Smets F, Reding R, de Ville de Goyet J, Sokal EM. Cryopreserved liver cell transplantation controls ornithine transcarbamylase deficient patient while awaiting liver transplantation. Am J Transplant 2005;5:2058-61.

19. Meyburg J, Hoerster F, Weitz J, Hoffmann GF, Schmidt J. Use of the middle colic vein for liver cell transplantation in infants and small children. Transplant Proc 2008;40:936-7.

20. Stephenne X, Najimi M, Sibille C, Nassogne MC, Smets F, Sokal EM. Sustained engraftment and tissue enzyme activity after liver cell transplantation for argininosuccinate lyase deficiency. Gastroenterology 2006;130:1317-23.

21. Fisher RA, Strom SC. Human hepatocyte transplantation: worldwide results. Transplantation 2006;82:441-9.

22. Fox IJ, Chowdhury JR, Kaufman SS, et al. Treatment of the Crigler-Najjar syndrome type I with hepatocyte transplantation. $N$ Engl J Med 1998;338:1422-6.

23. Darwish AA, Sokal E, Stephenne X, Najimi M, de Goyet Jde V, Reding R. Permanent access to the portal system for cellular transplantation using an implantable port device. Liver Transpl 2004;10:1213-5.

24. Terry C, Dhawan A, Mitry RR, et al. Optimization of the cryopreservation and thawing protocol for human hepatocytes for use in cell transplantation. Liver Transpl 2010;16:229-37.

25. Ambrosino G, Varotto S, Strom SC, et al. Isolated hepatocyte transplantation for Crigler-Najjar syndrome type 1. Cell Transplant 2005;14:151-7.

26. Allen KJ, Soriano HE. Liver cell transplantation: the road to clinical application. J Lab Clin Med 2001;138:298-312.

27. Lysy PA, Najimi M, Stephenne $X$, Bourgois A, Smets $F$, Sokal EM. Liver cell transplantation for Crigler-Najjar syndrome type I: update and perspectives. World J Gastroenterol 2008;14: 3464-70.

28. Khan AA, Parveen N, Mahaboob VS, et al. Treatment of CriglerNajjar syndrome type 1 by hepatic progenitor cell transplantation: a simple procedure for management of hyperbilirubinemia. Transplant Proc 2008;40:1148-50.

29. Muraca M, Gerunda G, Neri D, et al. Hepatocyte transplantation as a treatment for glycogen storage disease type 1a. Lancet 2002; 359:317-8.

30. Lee KW, Lee JH, Shin SW, et al. Hepatocyte transplantation for glycogen storage disease type 1b. Cell Transplant 2007;16: 629-37.

31. Sokal EM, Smets F, Bourgois A, et al. Hepatocyte transplantation in a 4-year-old girl with peroxisomal biogenesis disease: technique, safety, and metabolic follow-up. Transplantation 2003;76: $735-8$.

32. Grossman M, Rader DJ, Muller DW, et al. A pilot study of ex vivo gene therapy for homozygous familial hypercholesterolaemia. Nat Med 1995;1:1148-54.

33. Soriano H, Wood R, Kang D, Ozaki C, Finegold M, Bishoff F. Hepatocellular transplantation in children with fulminant liver failure. Hepatology 1997;26:239A.

34. Fisher RA, Bu D, Thompson M, et al. Defining hepatocellular chimerism in a liver failure patient bridged with hepatocyte infusion. Transplantation 2000;69:303-7.

35. Habibullah CM, Syed IH, Qamar A, Taher-Uz Z. Human fetal hepatocyte transplantation in patients with fulminant hepatic failure. Transplantation 1994;58:951-2.

36. Sterling RK, Fisher RA. Liver transplantation. Living donor, hepatocyte, and xenotransplantation. Clin Liver Dis 2001;5:431-60, vii.

37. Schneider A, Attaran M, Meier PN, et al. Hepatocyte transplantation in an acute liver failure due to mushroom poisoning. Transplantation 2006;82:1115-6.

38. Baccarani U, Adani GL, Sanna A, et al. Portal vein thrombosis after intraportal hepatocytes transplantation in a liver transplant recipient. Transpl Int 2005;18:750-4.

39. Mito M, Kusano M, Kawaura Y. Hepatocyte transplantation in man. Transplant Proc 1992;24:3052-3. 
40. Khan AA, Parveen N, Mahaboob VS, et al. Management of hyperbilirubinemia in biliary atresia by hepatic progenitor cell transplantation through hepatic artery: a case report. Transplant Proc 2008;40:1153-5.

41. Mitry RR, Hughes RD, Aw MM, et al. Human hepatocyte isolation and relationship of cell viability to early graft function. Cell Transplant 2003;12:69-74.

42. Bulte JW, Kraitchman DL. Iron oxide MR contrast agents for molecular and cellular imaging. NMR Biomed 2004;17:484-99.

43. So PW, Kalber T, Hunt D, et al. Efficient and rapid labeling of transplanted cell populations with superparamagnetic iron oxide nanoparticles using cell surface chemical biotinylation for in vivo monitoring by MRI. Cell Transplant 2010;19:419-29.
44. Puppi J, Mitry RR, Modo M, Dhawan A, Raja A, Hughes RD. Use of a clinically-approved iron oxide MRI contrast agent to label human hepatocytes. Cell Transplant 2011;20:963-75.

45. Dhawan A, Mitry RR, Hughes RD. Hepatocyte transplantation for liver-based metabolic disorders. J Inherit Metab Dis 2006;29: 431-5.

46. Shapiro AM, Lakey JR, Ryan EA, et al. Islet transplantation in seven patients with type 1 diabetes mellitus using a glucocorticoid-free immunosuppressive regimen. N Engl J Med 2000;343:230-8.

47. Kubota H, Reid LM. Clonogenic hepatoblasts, common precursorsfor hepatocytic and biliary lineages, are lacking classical major histocompatibility complex class I antigen. Proc Natl Acad Sci USA 2000;97:12132-7. 